Tér és Társadalom 17. évf. 2003/3. 199-202. p.

Tér és Társadalom

XVII. évf. 2003 - 3: 199-211

\title{
KÖNYVJELZÖ
}

\section{SZALAI ERZSÉBET: EZREDVÁLTÓ DILEMMÁK MAGYARORSZÁGON}

\author{
(Új Mandátum Könyvkiadó, Budapest, 2000, 238 o.)
}

\section{TÁTRAI PATRIK}

A kilencvenes évek és a mai Magyarország gazdasági és szociális problémái tárulnak fel Szalai Erzsébet kỏnyvében. A rendszerváltás gazdasági és társadalmi hatásai, a globalizációval megjelenő új kihívások, az értelmiség szerepe a maj Magyarországon, a nỏk helyzete a tudományban: megannyi kérdés, melyekre válaszokat keres a szerzỏ a kötetben.

A könyv 1998 és 2000 vége között a Kritikában, az Élet és Irodalomban valamint a Népszabadságban megjelent politológiai, szociológiai témájú tanulmányokat, esszéket, publicisztikákat köti csokorba. Három nagyobb egységból áll. Az első tartalmazza a szerző nagyobb terjedelmủ, átfogó esszéit, tanulmányait, a második a Népszabadságban megjelent írásait fúzi össze, míg a harmadik egy válogatás az Élet és Irodalomban különbỏző szerzőktől megjelent írásokból (Vita a tudás és az értelmiség társadalmi szerepéröl).

A kötet első írása (Értelmiségi szerepek az ezredvégen) az értelmiség helykeresését vizsgálja. Szalai szerint a mai magyar értelmiség három nagyobb csoportra osztható: a médiasztárokra, a tudományos, illetve a kritikai értelmiségre. Az első két csoportra eröteljesen hat a politika és a piac. A médiasztárok esetében fontos a közönség támasztotta kereslet is, a tudományos értelmiség viszont sokszor manipulálható. Akiket e két csoport kizár magából - a szintézisre való törekvése miatt -, azokat nevezi Szalai kritikai értelmiséginek.

A szerző e meghatározások után ismerteti a kritikaj értelmiség feladatát, helyzetét, belső tagolódását. Fontosnak látja e csoport szerepét, hiszen „az értelmiség felé irányuló társadalmi szükséglet - mint a folyamatok (ti. a korábbi struktúrák szétesése, a társadalom individualizációja) értelmezóje iránti szükséglet - nö". Összességében szükségesnek látja a kritikai értelmiségi szerep megújítását, melyet két okra vezet vissza: a gazdasági elitek növekvő erőfölényére, illetve a szerző szerint elengedhetetlenül szükséges holisztikus szemléletmód alkalmazására.

A második tanulmány (Szociális vagy társadalmi érzékenység) a nagy ,jövedelem-átszivattyúzások" után végbemenő forrás-újraelosztás hatásaival, valamint a szegénypolitikákkal foglalkozik. A rendszerváltás utáni időszakban a szegénység tơmegessé vált, ami a magas munkanélküliséggel együtt a globalizálódó világ jellemzöjeként is meghatározható. Szalai kifejti: egyre nagyobb társadalmi feszuiltsé- 
geket okoz a szegények és gazdagok közötti szakadék folyamatos növekedése, azaz egyre kevesebbek birtokolnak egyre több jövedelmet.

Magyarországra tekintve Szalai megállapítja, hogy a kilencvenes évek közepére lényegében befejeződött a rendelkezésre álló források újraelosztása. A társadalom szerkezete stabilizálódott, $\mathrm{s}$ megkezdödött a különbségek generációs átörökítése. A szerző elénk festett jövőképe nem túl bíztató: „Az elkövetkezö években a legnagyobb realitását (...) jelentös társadalmi csoportok csendes lecsúszásának, az ebbe való csendes belenyugvásnak és az atomizáció erösödésének látom".

Szalai Erzsébet harmadik írása (Tarsis vagy Ninive) több, egymással laza kapcsolatban levő gondolatmenetböl áll össze. Központi témája a rendszerváltás, annak előnyei, hátrányai esetleges alternatívái. Megfogalmazza a rendszerváltás erkölcsi alapkérdését: „Vajon morálisan joga van-e a társadalom egy kisebbségének a többség áldozatvállalását követelni, miközben ö maga nemhogy áldozatot nem hoz (még a gesztus szintjén sem), de rohamosan gyarapszik."

A következő írás címe: A puccs, azaz a Bokros-csomag szociológiai elözményei, háttere, következményei. E roppant érdekes írás több interjúra épül, köztük Horn Gyula visszaemlékezéseire. Szalai úgy láttatja a kilencvenes évek közepének politikai, gazdasági útvesztöjét, hogy közben mindvégig háttérben marad, egy-egy kommentáron kívül nem jelenik meg. Remekül „összerakta” ezt a részt, izgalmas, lebilincselő olvasmány, mely bemutatja a lobbik nyomását a kormányra, a nagyvállalatok szerepét a politikai döntésekben, valamint a Bokros-csomag gazdasági előzményeit. Megítélésem szerint Szalai nem tartotta szükségszerünek és megalapozottnak a Bokros-csomagot. Létrejöttét a késő kádári technokrácia hatalomra kerülésével magyarázza, az intézkedéseiket pedig reformdiktatúrának tartja.

Az első rész utolsó írása a gazdasági hatalom szerkezetével foglalkozik. A szerzö arra a kérdésre keresi a választ, hogy kik birtokolják ma a gazdasági hatalmat, és hogyan tettek szert rá. Szalai először ismerteti a magyarországi szocializmus nagyvállalati rendszerét, annak felbomlását, privatizációját. A magyar tulajdonosok mellett a privatizáció során megjelentek a külföldiek is. A magyar gazdaságpolitika és privatizáció sajátosságai miatt a külföldi tulajdon aránya igen magas. A folyamat maga komoly tulajdonosi koncentrációt okozott. A szerző ezek után statisztikai adatokkal támasztja alá a multinacionális nagyvállalatok kimagasló szerepét, illetve a kisvállalatok relatív megerösödését. Rámutat arra is, hogy a kis- és középvállalatok, illetve a nagyvállalatok között alig van kapcsolat. Összegzésképpen azt írja, hogy a magyar tulajdon- és vállalatszerkezet nem hasonlít sem a nyugati, sem az ázsiai, sem a posztszocialista struktúrákhoz. ,A magyar modell leglényegesebb tulajdonsága a külföldi tulajdon dominanciája." Megítélésem szerint ezen írás bátor kísérlet a magyarországi tulajdonosi kör feltérképezésére, de alapvetỏ adatok hiányában e kísérlet csak részben járhatott sikerrel.

A könyv második részében Szalai publicisztikai írásait találjuk. Témakörük változatos: az aktuálpolitikai kérdésektől, az elméleti témákig sok minden megtalálható. Különösen foglalkoztatja a nők helyzete a posztmodern társadalomban és a tudományban (Nők a tudományban, Védett férfiak?); a politikai kultúrharc (Tétek és 
befutók, Szekértáborok mögött); a háború, annak hatása az értelmiségre, a hábonús manipuláció (Regresszió, Megússzuk?); az individualizálódó társadalom (A kis herceg ma).

A könyv befejező része, a Vita a tudás és az értelmiség társadalmi szerepéről az Élet és Irodalomban megjelent cikkekböl közölt válogatás. Mint a címe is mutatja, ez egy vita volt, mely két fő kérdés körül forgott. Az egyikben a szerzők az értelmiség helyzetét, szerepét, feladatát vizsgálták, a másikban a tudás, a tudásipar, a tudástermelés és az oktatás témáit járták körül.

Szalai Erzsébet kritikai értelmiségiként írt könyve a politológia és a szociológia határai között mozog, s nagyfokú társadalmi érzékenységről tesz tanúbizonyságot. Ajánlható mindenkinek, akit érdekelnek a rendszerváltás után felmerülő problémák, kérdések, és a rájuk adott válaszok, s a globalizáció új kihívásai. Ajánlható azoknak is, akik kíváncsiak a társadalmi egyenlőtlenség mélyebb okaira, s az értelmiség új feladataira. 
Tér és Társadalom 17. évf. 2003/3. 199-211. p.

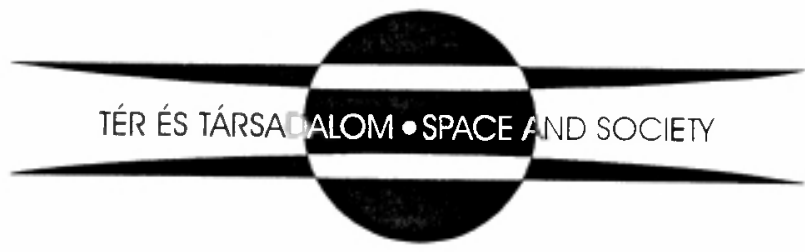

